\title{
THE MESSAGE OF MONISM TO THE WORLD.
}

W

E LIVE in an age of the intensest mental growth. Science penetrates deeper and deeper into the secrets of being, teaching us at the same time the conditions of improvement and progress; while the results of our more complete insight into the nature of things have matured our whole trend of thought and rendered our world-conception more sober, more positive, and clearer. The new philosophy which is dawning upon mankind has been briefly called Monism, or the theory of oneness, which indicates that the world, we ourselves included, must be conceived as one great whole. All generalisations, such as matter, mind, and motion, are abstractions representing aspects of reality, but not entities or things-in-themselves by a combination of which the universe has been pieced together; and all our notions of nature can be formulated in exact statements, which, when properly understood, form one harmonious system of natural laws. Monism is the product of the scientific tendencies of our age; it is the principle that pervades them; it is their consummation, and in it the spirit of modern science is concentrated, as it were, in its quintessence. As such, Monism not only forms a centre for the various specialties of scientific research, throwing light upon their interrelations and their aims, but is also destined to penetrate the public mind, to rally, to render judicious, and to direct all efforts at reform, and to regenerate our entire spiritual life in all its various fields. We ask, therefore, what is the message of Monism to the world, and how can it quicken the main-springs of our social, ethical, artistic, and religious aspirations?

Philosophy is not mere theory; it is not an elaboration of ideas 
without practical consequences; philosophy shapes our world-conception, and our world-conception gives color to our whole frame of mind and powerfully influences all our actions. Thus, it is the basis of all our thoughts and inclinations. It is the vital centre of our entire being, and only those ideas which touch it are of a sweeping importance. No progress is stable unless it begins here, and no reform is thoroughgoing unless it plunges its roots into these deepest convictions of our soul.

Monism has to struggle for existence, and must overcome the powers which still sway the mass of mankind. And these powers are very strong, - not because they possess much vitality, for they are dying off, and present the sad spectacle of stagnant indifference, but because they hang like a dead weight on the minds of men; their strength is the inertia of massive mountains, the organised life of which has been ossified in palæontological fossils. The era of transition, having given rise to many abortive endeavors to find a way of escape from the pharisaical dogmatism of the old supernaturalism, has ended in the intellectual death of philosophy, which has become satisfied with the negations of an indolent Agnosticism.

In discoursing upon Monism, I do not speak pro domo, I do not refer to my own philosophy, but mean that whole great movement in the realm of human thought which endeavors to work out a systematic world-conception upon the basis of a methodical observation of facts. On the other hand, when I speak of Agnosticism as being indolent, I here deliberately exclude both the inventor of the term and its chief representative. Far be it from me to brand their personal endeavors as indolent or to be blind to the great merits of their life-work. I cannot help, however, saying that their philosophical doctrines exercise a pernicious influence, which is obviously productive of indolence and indifference. Thus be it understood that when I speak of Agnosticism I mean the attitude of surrender which writes upon its colors the desperate motto ignorabimus, and maintains that the fundamental problems of life are unanswerable riddles.

Monism does not deny that there are and always will be unsolved problems; it is not the proclamation of a dogmatic omniscience; it simply maintains that knowledge is possible, and that the problems 
which confront us, among them the very important practical problems of the principles of ethics, the ultimate authority of moral conduct, the nature of the soul and the destiny of the soul after death, are by no means unsolvable. Agnosticism, in rejecting the dogmas of our religious traditions, denies that we can know anything at all about God, soul, and immortality. Thus it discredits investigation, and, leading us into a blind alley, arrests intellectual progress. And so convenient is this attitude concerning the most important problems, the solutions of which, if boldly pronounced, are apt to give offence in some way or other, that the indolent and indifferent of all parties assume it; above all, the representatives of reaction parade it with an ostentatious pretence of breadth and liberalism. The natural consequence of it is that the children of our time have become shallow and exhibit a lamentable lack of character, which appears in the methods of education, in the productions of art, in the religion of our churches, and in the principles of moral conduct. Monism has a word to say on all these subjects. Monism does not overthrow the old traditions; it does not begin the world $a b$ ovo; it does not destroy the harvest of millenniums. On the contrary, it embodies in itself the rich experience of past ages; it gathers the golden sheaves in its garners; it only winnows the wheat from the chaff, rejecting the false, the irrational, the hypocritical, the dead letter, and preserving the good, the true, and the truly religious. It prunes the future growth, it systematises, purifies, and elevates. It renovates the old faith; it transforms childlike dreams into distinct conceptions, and changes the fairy-tales of our religious hopes into scientific truths, pregnant with manly resolutions and fixed determinations. Thus, Mo. nism brings into the world a new faith, which undertakes to move the mountains of agnostic incompetence and fashionable indifference.*

* My agnostic friends say that I am prejudiced against agnosticism, and that I do not understand its proper meaning. $I$ repeat here what $I$ have said on former occasions, that $I$ am an adherent of the agnosticism of modesty, which remains conscious of how little we know, but I object to the agnosticism of arrogance, whose devotees dogmatically declare, "We do not know, and thus no one can know." It is true enough that the world as a whole and in all its details is wonderful; here we are, and here is the world in which we have developed; and we say with Goethe: "Zum Erstaunen bin ich da!" If that be the meaning of agnosticism, I 
The message of Monism appeals to every man who is serious in the investigation of truth, and its applications to practical life are important. Laborers are wanted in all the various fields of human exertion.

Permit me here to sketch the suggestions of this message in three great fields : first, in the domain of practical psychology touch. ing questions of education, the judiciary, and the treatment of criminals; secondly, in the domain of public life, choosing for special consideration the much neglected topic of art; and lastly, in the religious field of our church institutions.

I.

The central problem of psychology is concerned with the nature of the ego-conception. There are the ideas, " $I$ think; $I$ feel pain; $I$ feel pleasure ; $I$ desire to do this, and it is $I$ who do it." And by $I$ we understand this whole personality of ours. The old psychology assumes the existence of a mysterious soul-entity which acts the part of the ego and is supposed to be the agent of our psychical activity. We need not enter here into a detailed explanation of all the difficulties into which this view implicates us, for they are innumerable and insurmountable, so that the last refuge of those who hold it is the agnostic position that the problem of the soul is too

am an agnostic. But our agnostic philosophers do not dwell on this feature of existence ; in fact, I do not know that they mention it. Their explanation of agnosticism is different. An event, or a natural law, or any phenomenon, such as a rainbow, may be wonderful, glorious, astonishing, dazzling, or strangely surprising, and yet perfectly intelligible and comprehensible. This, in my opinion, is actually the case with existence. The world as a whole, the cosmic order and every detail of reality, is wonderful yet at the same time perfectly intelligible, and here I differ from the agnostic position. Agnosticism declares that existence is incomprehensible, and that the fundamental problems of existence, such as the existence of God, the nature of the mind, the origin of consciousness, the relation between soul and body, are absolutely unsolvable. This produces a comfortable but vain self-sufficiency in the minds of those who are either unwilling or unable to think a problem to the end; it acts as a check on progress and surrounds confusion of thought with a balo of apparent philosophical sublimity. See Homilies of Science, "The Questions of Agnosticism "; Fundamental Problems, "The Stronghold of Mysticism," pp. 213220 and passim. See also the controversy on agnosticism in No. 212 of The Open Court. Concerning such questions as the squaring of the circle see Fundamental Problems, Second Edition, p. 283, "The Unsolvable Problem," and p. 291, "The Unanswerable Riddle." 
deep for solution. A monistic psychology has no room for a metaphysical ego-entity; it shows with good arguments and proves by experiments, of which the most striking ones have been collected by Monsieur Ribot in his excellent psychological memoirs, that the idea of an ego-entity is an illusion. The thought "I" is one idea among many others, having grown into prominence by its frequent occurrence. The soul of man is comparable to a society or an organised state, the citizens of which are so many ideas, impulses, and volitions. At first sight this new soul-conception appears appalling, for it seems to be a negation of the existence of the soul, and it has actually become customary to characterise it as the psychology without a soul. This, however, is not so. The new psychology denies only an unwarranted assumption which, if it were true, would not add an iota to the dignity of the human soul; it only rejects an error, it protests against a superstitious, and, what is more, an injurious, misconception. The change which it brings about is similar to the advance of astronomy from the old Ptolemaic view, which mistook the earth for the centre of the world, to the Copernican system which regards it as one of the planets revolving around the sun. The illusion of the stability of the ego at the centre of our psychic activity is dispelled, but the reality of our soul remains the same as before. On the contrary, the world of mental life is extended not less than the new conception of the astronomical heavens; and the traditional dogma of immortality appears in a new light more glorious, more comforting, more elevating than the fantastic notion of a continued ego-existence in a heaven beyond the clouds.

The negation of the existence of the ego-entity, which many psychologists identify with the soul, is as old as Buddha and perhaps older; yet the application of this truth in the domain of religion is little appreciated and even misunderstood. Its representatives, as a rule, press only the negative side of this view, probably because they do not see the positive side and its great importance. It is as if some myth-poet had personified the day and spoke about it as the bearer of the sunlight, or the "subject" of which all the phases of solar radiance, from morning to night, were phenomenal aspects. Should, now, a philosopher come and explain the nature 
of the day, declaring that day is not a subject of phenomenal events, not a bearer or metaphysical entity but only a name for a series of events, he might be denounced for nihilism and suspected of believing in the non existence of light. Those who believe that day is an entity, regard sunset as the death of day. But in the soul-conception of monism death disappears as much as sunset ceases to be an event that touches the sun.

The practical applications of the new psychology demand, and have even partly brought about, a revision of our entire system of education from infancy to the psychical dietetics of the adult. We want poets who will give us in the place of the old silly doggerels new nursery rhymes, pictures and simple stories conveying instruction as well as moral truths in a telling way. No doubt improvements have been made, but we still look in vain for a model picture-book, perfectly adapted for babes just beginning to speak. Grimm's and other fairy-tales for children will have to be revised, but the revision must be made with an artist's hand; their beauties will have to be retained while their monstrosities must be removed or at least toned down. New tales must be added. The child of to-day who is accustomed to railway travelling and to the sight of machinery will be interested to hear, for example, that there was a time when no engines existed, and that the little boy who once watched the steam of the tea-kettle lift its lid, when he became a man invented the boiler and the cylinder in which the confined steam drives the piston and makes it perform work. It is not easy to reduce the experiences which most of us have had in later life to simple expressions fitted for the comprehension of children, but it is possible and necessary.

The methods of school instruction must be improved. When our educators consider the nature of mind and its growth from senseimpressions, they will, as much as possible, confront the pupil with facts. The principle of teaching by object-lessons must be carried up to the highest branches of physics and mathematics, not omitting languages. Train not only the mind by theories, but impart sensations. Have plenty of illustrations. Use to advantage wherever feasible the magic lantern in geography, in history, in 
literature, and art. Teach Latin and Greek syntax in little stories which when learned by heart will naturally and without effort make the pupil apply grammatical rules correctly. It is possible to teach any language, Latin, Greek, or Hebrew, to a youth of average intelligence within a year so that he shall be able to understand it when spoken, and to read and write it. To train the ear by listening to the spoken language, the eye by the sight of printed words, the hand by writing them, and the mind by the abstract comprehension of rules, all at once, is in the long run not.more difficult, but easier-namely, easier to the pupil-than a one-sided instruction. In the same way a long sentence of about three lines is more easily remembered than three disconnected words. The home work of our children can be greatly reduced if knowledge is imparted in a systematic and more impressive way. The problem is simply a matter of improved method, of building everything upon the strong foundation of a vivid sense-experience, of invoking the mutual assistance of the senses, and of concentrating all efforts upon points of practical importance. While we should expect more intensified work of our teachers we must at the same give them more leisure for preparation and study.

Splendid beginnings have been made with gymnastics and manual training, but they ought to be generally applied and need not be confined to manual training-schools and technical institutes.

Let us have less work and fewer lessons but more clearness in the presentation of the subjects of instruction in our schools. Drop what is redundant and introduce what is indispensable. Mathematics as a rule is too much neglected and where it is taught should receive more life and fervor. Mathematics need not be so dry and tedious as it is commonly regarded. A mathematical teacher should awaken in his scholars a holy enthusiasm for this most beautiful and divinest of sciences.

We must also change our attitude towards errors, mistakes, vices, and crimes. The old idea of retaliatory justice has been replaced by the two greatest religious teachers of the world, by Buddha and by Christ, who put in its stead an all-embracing compassion for the suffering. They taught a doctrine which has but lately been under- 
stood. The monistic philosophy, it can truly be said, has discovered the scientific basis of Christian ethics. The principle of egotism has commonly been regarded as the natural law of moral conduct, and the higher view of superindividual maxims, it was claimed, could not have been naturally developed; it must have been proclaimed by a supernatural revelation. Monism, by dispelling the illusion of the ego, points out the way to a nobler system of ethics, not based upon supernatural revelations that stand in contradiction to the facts of nature but upon the higher evolution of nature in her best children who understand their mother better than do the lower and less perfected creatures, who thus in fact stand nearer to nature, and in this sense are more natural than they. Our modern world-conception considers that the criminal is the product of conditions. It may be necessary to shoot a tiger that is at large, but there is no sense in punishing him because he killed a man. Criminals have been classed with the insane, and treated as morally diseased. The amputation of an ulcerated or cancerous limb is no punishment of the limb, but a cure to protect the other limbs and save the life of the man. It must be remembered that we do not advocate a humane treatment of criminals from sentimental reasons which in their application often lead to a gross injustice toward those who suffer from the folly and brutality of criminals. We simply take the ground of treating men as we treat things, viz., according to their nature without any ill-will or hatred. I remember the lesson which I received while living in Europe from an old French landlady who in anger smashed a Chinese vase because she could not remove a stain as quickly as she wanted to. How often does the retaliatory justice of a barbarous past still lingering with us, destroy human souls from mere impatience.

Punishment is only justified as an educational or protective means, and as such, it ceases to be punishment in the original sense of the word. We have learned with Christ to hate sin while not hating the sinner, and to treat him with all the regard that his humanity demands 
II.

Monism has not yet been able to exert its wholesome influence upon the public life of society and politics. We should always bear in mind that in the end all our institutions must serve to develop a higher humanity in man, more manliness, a prouder self-reliance, independence of character, better information, and nobler ideals. It is good for us Americans that we suffer from the ignorance of our voters, but we must not be satisfied with the present conditions. On the one hand, let us remove from our public life the temptations of the spoils-system, which often actually places a premium upon dishonesty, and favors the unscrupulous party-politician. On the other hand, let us consider that our republican institutions can be preserved only on the condition of a general progress of the intelligence and moral firmness of the average man.

Among many other reforms we demand a regeneration of the spirit of art. Art at present is degraded; it has become mere fashion and the representation of empty elegance. Technicalities have become the standard of artistic beauty, while philosophical depth and religious earnestness are omitted and almost discredited.

In former times the world-conception of the age sought embodiment in lofty creations of art. Every piece of art was the expression of the spirit of the times. Art was holy to the Egyptians, to the Greeks, to a Michael Angelo, a Holbein, a Dürer. The religion of the ancient artists speaks to us from the wonderful works of their hands. What is the art of to-day? It consists in the production of beautiful forms wrought out with refined skill by able artificers, but it is void of ideas, possesses no holy zeal, and is utterly lacking in meaning and purport. Why is there no Shakespeare living among us now, no Goethe, no Schiller? It is not be cause the necessary talent is absent in our young men, but because there is no demand for a poetry that will undertake to teach man. kind and reflect the deepest philosophy of the day in a form in which it would be directly and intuitively understood. We cannot say that the people at large are averse to a treatment of the deepest 
problems, for even comparatively weak novels on religious, philosophical, and social problems have proved a great temporary, although on account of their shortcomings, not a lasting success. The truth is, that our leaders in literature, our critics, our prominent artists, are infected with the Agnosticism of our age. As Agnosticism has pooh-poohed the manliness of having a definite conviction, the characteristic feature of the art of our age is to be void of character.

The first step toward this sorry condition of art was taken by a great man in a mistaken zeal for the liberation of art from the dogmatic world-conception of an antiquated and narrow-minded theology. Lessing pronounced in his great work on Laökoön the principle that art should be devoted to the representation of the beautiful and must not be subjected to the censorship of the moralist, who would only use it for the exposition of a bigoted Sunday-school morality. Lessing branded all creations of art that sought to be inspired by philosophical or religious ideals as tendency- or purposeproductions. With apparent justice he claimed art for art, dedicat ing the beautiful to the beautiful, and leaving the elaboration of truth to science and philosophy, or to religion. He was actuated in the enunciation of his erroneous principle by his zeal against the ruling dogmatism of his age, which actually choked all true art. Lessing did not consider that the beautiful cannot be separated from the true; that while the unreal may be sublime and noble, nay, even true, the untrue is always ugly; and that if art, by showing us the world or some part of the world, the inanimate nature of landscapes or the psychic nature of our souls, in the transfiguration of beauty, did not teach and instruct us, if it did not purify and elevate our minds, it would be like a sounding brass or a tinkling cymbal. Art ceases to be art and is mere artificiality as soon as it is nothing but beauty without truth, form without idea, pleasing creations without meaning.

The best refutation of Lessing's principle is given by himself ; for as a poet he disregarded his own rules; and his best works, if not all, would have to be condemned as purpose-dramas. What are "Nathan the Wise," "Minna of Barnhelm," "The Jews," but 
works of art that have a very obvious purpose; they teach moral lessons and are unmistakable expressions of his world-conception. The same is true of all other great dramas, such as "Antigone," "Hamlet," "Faust"; which were not written merely to make a display of literary beauty, but to incorporate the deepest religious and philosophical convictions of their poets. They please and teach at the same time; and concerning Lessing's dramas we know for certain that he actually intended them not so much to please as to teach. According to his own confession he used the stage as his pulpit.

It is a shame and a testimonial of our intellectual poverty that such senseless pieces as "The Babes in the Wood," and even worse productions, have been played to crowded houses, that they were praised by the press, and could be repeated in all our great cities more than a hundred times. Would that some wealthy man might found a theatre devoted to true art! The stage could be made a source of spiritual blessings more influential than the church. It would be a powerful factor in the regeneration of our age.

The most prominent philosopher of Agnosticism declares the origin and nature of art to consist in "the useless and superfluous exercise of human faculties." He identifies art with sport, from the practices of which he selects his explanatory examples, and finds the standard of its evolution-begotten perfection in its increasing complexity. From this conception of art the soul is gone; the only thing left is the skill of physical and mental acrobats. An organ solo would be superior to the playing of a piano, because the former is more complex, for while the pianist uses his hands only, the organist has to use also his feet; and the clown who plays the fiddle on horseback would rank higher than Paganini. Such is the agnostic idea of art! Since Agnosticism renders a positive conviction as to the nature of existence impossible, it is consistent with its main principle to take away from art its innermost meaning, its very soul and sacred purpose, which consists in being the expression of a worldconception. We children of a transitional age of indefiniteness are so imbued with this lack of character that the emptiness of our artproductions does no longer surprise us. The present generation, it seems, has lost the proper understanding for true art, because the 
world-conception of the masses has become an empty blank; and there is no hope of reform until we regain for our convictions the religious earnestness and ardor which distinguishes all the great artists of former ages.

III.

If Monism is true, our entire religious life will have to undergo a radical change. The dual system of religious truth and scientific truth must go. We must face the fact that there is but one truth and that all different truths are but aspects of that one truth. Science is a religious revelation equally as grand as the Psalms of David and assuredly not less reliable than the visions of St. John.

Our religious leaders must recognise the principle of scientific investigation as the proper method of ascertaining religious truth. The churches must abandon the imposition of pledging the clergy to special dogmas; they might at their ordination pledge them to a reverence of the traditions of their special creeds, but should demand no higher vow than an allegiance to truth.

The present system of many great ecclesiastical institutions deliberately makes hypocrites of the teachers of the people, for it enjoins upon their consciences in a most solemn way some oldfashioned and indeed ridiculous tenets which it is impossible for any sane person of the present century to countenance. Not even the Archbishop of Canterbury can be suspected of believing all the thirty-nine articles of his church, and if he does, he has either to interpret their original meaning away, or to stretch his conscience.

The churches have to be broadened, but, on the other hand, our secular aspirations after progress have to be impressed with a religious spirit. The liberalism of our times, good as it is in its principles, often pursues wrong aims. Thus, in the interest of a strict impartiality toward all religions, ordinances are in force in some of the United States, which forbid the reading of the Bible in public schools. Can the interdiction of the most important collection of sacred literature that exists be called liberty? True, the idea is, not to let the children be impressed with any one of the various sectarian interpretations of the Scriptures, but shall our young men and wo- 
men for that reason remain entirely ignorant of the contents of the Bible? The consequence is, that in this country where the mass of the people are unchurched, more than fifty per cent have never read the Bible; and truly, we might rather omit Homer or banish Shakespeare than the History of Israel, the Psalms, and the Gospels. I know the difficulty lies in the sectarian spirit in which our various sects want the Bible read, and its miracles literally believed, but why not let the churches give their own interpretation in their Sunday-schools while the public educational institutions give simply an exposition of facts.

We suggest going further still : not only from the Bible but also from the sacred literature of other religions should selections be read. There are some beautiful passages in the Koran, there is the magnificent Bhagavadgîtâ of the Hindus, there is the Tâo Tĕh King of Lâotsze, full of Christian ethics, although written six hundred years before Christ ; there is the Buddhist Dhammapada, the sentiments of which are throughout as lofty as the most glorious passages of the New Testament. All these sacred writings should be household books in our homes, schools, and universities. Together with the Bible they should all be read, reread, and studied with diligence, for they offer us the spiritual bread that is needed so much in our public and private life.

It has been claimed that it is impossible to study religious subjects with impartiality, but why should it be so? If it is impossible now, we must make it possible. What has not been said to be impossible that afterwards has become an actual fact? We have had in this city that memorable gathering of the World's Parliament of Religions, which is a most wonderful event in history, the lesson of which has not as yet been generally learned or even appreciated. If our people understand its lessons they will not hesitate to teach religion in our public schools with all the impartiality that the love of truth demands.

It is quite possible to write a text-book adapted to the capacity of our children in the public schools which in large outlines would characterise the great religious systems of the world so that no one of their adherents would have cause to find fault with the statement, 
and which at the same time would contain selections from the various sacred literatures. Shall we forbid the eating of bread because it is liable to become mouldy and poisonous? No, let us show our impartiality not by suppressing the most important discipline but by teaching the facts, so far as they are undeniable, in a way adapted to the age of the pupils and with due discretion so as to avoid unnecessary offence. But under all circumstances let truth be the ultimate tribunal of appeal.

Monism does not advocate a revolution in religion but a reform ; yet the reform must be radical ; it must dispose of all falsehood at the roots of our religious life.

Let me here express my conviction that the intellectual life of our ecclesiastical institutions is not as dead as it frequently appears to outsiders. The churches still contain powerful potentialities. Any one who cares to investigate matters will observe the thriving and sprouting of promising germs that are developing higher forms of religious life. There exist religious thinkers who take their stand upon the properly religious maxims of religion, who rigorously follow the truth, not only in judging themselves, but also their religious ideas, and in investigating the records of the Bible; who discriminate between the essential and accidental, and find the orthodox solution of difficulties not in the literal acceptance of the letter but in the spiritual meaning of the sacred traditions. They must in the end find the right solution of the religious problem, and will then be able to meet the demands of the so-called infidel world, which is slowly but surely learning to recognise the subtle but very real truths of spiritual and moral laws that obtain in nature.

While there are unmistakable symptoms of progress in many of our old established institutions, it is strange that the most liberal churches sometimes appear the most timid. They halt in their advance as though they were afraid of falling a prey to negativism. This is perhaps the reason why the Unitarianism of to-day shows less vitality than in the days of Channing and Parker. Our Unitarians and the other liberal churches must learn how to be conservative and progressive at the same time. Nor must they be afraid of struggle. Those movements only which have an aim, which are 
inaugurated to do some work, which struggle for a cause and pursue an ideal, can be said to be living powers in the world.

There is a widely spread preconception on the subject of religious reform which is that if we begin at all it will finally lead to the utter extinction of religion. But we beg to differ from this view. We consider it as a necessity to carry reform, as demanded by science, to its most radical extreme. Religion will not suffer, but, on the contrary, be purified. The essence of all religion lies in the practical application of truth; the sole purpose of religion is to teach man ethics, to make him a moral enthusiast, to point out to him the way to salvation. And there is no other saviour but truth. Now there is no religion, be its dogmas ever so crude and irrational, but has in it the potentiality of developing into a religion of truth. There is no religion, be it ever so low, that does not purport to be, and can become, an ethical religion. Let but Christianity be true to the spirit of reform which Christ's injunctions breathe, and it will be found to be true. Many of those Christians who call themselves orthodox, spurn the search for truth undertaken by science for the sake of dogmas founded upon the views of well-intentioned but narrow-minded and ignorant men. They have nothing of the spirit of Christ. Verily, he who trusting in truth and believing in the oneness of truth embraces the simple faith in a religion of truth, is a better Christian than all the Christians in name. He is truly orthodox, that is, of right faith; he may discard the letter of Christianity, yet he preserves the spirit; he may protest against the literal interpretation of its mythology, yet he possesses its meaning; he may not be baptised, yet Christ's ideal of a superindividual life lives in his heart; the ethical faith of the religion of truth alone-of scientifically provable truth is-catholic, for no truth is catholic except it be demonstrated by science.

Monism bids the religious thinker be bold and use fearlessly his natural right, or rather obey his duty, of free investigation. The meaning of the old religions is true enough. What renders them objectionable is a clinging to the allegories of their faith and an unthinking acceptance of the symbol as if it were the truth itself. As soon as our churches begin to take the spirit of their religion seriously and to throw off the paganism of a worship of the letter, they 
will develop a higher orthodoxy, which can never come in conflict with science and will exhibit an unexpected agreement with the conclusions of a most radical and fearless Monism.

The new world-conception grounded upon the facts of experience as stated with the scrupulous methods of exact science and systematised by a positive and monistic philosophy, throws light upon all the provinces of human exertion. It brings into full consciousness many aspirations which have so far only been the expression of instinctive promptings. It helps us to understand the nature of our own self, the destiny of our life, and the aim of our holiest ideals. It gives direction to all our yearnings and fulfils all legitimate hopes; it gathers the harvest of the past, and brings everything to a consummation, which, however, will only be the starting-point of a higher development with broader outlooks and infinitely greater possibilities in all the domains of human exertion.

EDITOR. 